\title{
Assessing the social costs of urban transport infrastructure options in low and middle income countries
}

Tam $\mathrm{Vu}^{\mathrm{a}, \mathrm{b},{ }^{*}}$ and John Preston ${ }^{\mathrm{a}}$

${ }^{a}$ Transportation Research Group, Faculty of Engineering and Physical Sciences, University of Southampton, UK; ${ }^{b}$ Faculty of Transportation Engineering, National University of Civil Engineering, Vietnam

*Corresponding author. Faculty of Engineering and Physical Sciences, University of Southampton, Boldrewood Innovation Campus, Burgess Road, Southampton, SO16 7QF; Email: mtv1g12@soton.ac.uk.

ORCID

John Preston https://orcid.org/0000-0002-6866-049X 


\title{
Assessing the social costs of urban transport infrastructure options in low and middle income countries
}

\author{
Abstract: This paper develops cost models for urban transport infrastructure \\ options in situations where motorcycles and various forms of taxis are important \\ modes of transport. The total social costs (TSCs) of conventional bus, Bus Rapid \\ Transit (BRT), Monorail, Metro (Elevated Rail), car, motorcycle, Taxi and Uber \\ are calculated for an urban corridor covering operator, user and external costs. \\ Based on the parameters for a $7 \mathrm{~km}$ corridor in Hanoi, Vietnam, the results show \\ the lowest average social cost (ASC) transport modes for different ranges of \\ demand. Motorcycle might be the best option at low demand levels while \\ conventional bus has advantages with low-medium demand. At medium demand \\ levels, bus-based technologies and Monorail are competitive options while \\ Metro, with a higher person capacity, is the best alternative at the highest demand \\ levels. Compared to other modes, the ASCs of car and Taxi/Uber are greater \\ because of high capital cost (related to vehicles) per passenger and low \\ occupancy. Transport planners and decision makers in low and middle income \\ countries (LMICs) can draw on the findings of this study. However, a few \\ limitations are identified and additional research suggested.
}

Keywords: social cost model; private transport; public transport; demand responsive transit

Word count: 7730

\section{Introduction}

Due to the rapid development of technology and increasing demands for travelling in urban areas, Demand Responsive Transit (DRT) and innovative Public Transport (PT) technologies, rather than conventional bus and heavy rail transit, have come into focus, 
particularly in LMICs ${ }^{1}$. In many low and middle income cities and countries, the background trend is a significant increase in private vehicle (car and motorcycle) users in mixed traffic environments, especially in urban areas of Asia (e.g. Indonesia, Malaysia, Thailand and Vietnam). The dominance of motorcycles in mixed traffic environments seems to cause some transport problems such as traffic congestion, air pollution, noise pollution and traffic accident (Chang and Yeh 2006, Bray and Holyoak 2015). To solve these challenges and to increase the modal share of PT, these countries have invested in several PT projects such as BRT, Metro and Monorail (Malaysia Economic Planning Unit 2010, Government of Vietnam 2016). However, there seems to be very little evidence on comparative costs for motorcycles, cars, DRT and PT technologies to identify the most cost-effective transport mode. As a result, this study assesses several transport infrastructure options by comparing the total social costs of these passenger modes on an urban corridor. The structure of this paper is as follows. Section 2 discusses previous studies on cost models. Section 3 describes the transport social cost models (SCMs), including those for PT, DRT and private transport (PRV). Hanoi, the capital of Vietnam, is chosen as a case study, which is introduced in detail in Section 4. Section 5 illustrates the key results of the intermodal comparisons. Section 6 draws some conclusions and discusses potential future work.

\section{Literature review}

There has been a series of studies on cost models built for high income countries (HICs) following the pioneering study of Meyer, Kain, and Wohl (1965). The authors analysed

\footnotetext{
${ }^{1}$ As of $1^{\text {st }}$ July, 2019, LMICs are defined as those with a Gross National Income (GNI) per capita, calculated using the Atlas method, of US\$ 12,375 or less in 2018 (World Bank 2019).
} 
comparative costs for different transit modes (rail, express bus, flier bus) and automobile for three scenarios (6-mile, 10-mile and 15-mile service) in both medium population densities and high population densities. Meyer, Kain, and Wohl (1965) defined total social cost include operator cost and user cost and the measure of cost effectiveness is average passenger trip cost. The results showed that costs for all PT services decrease as a function of hourly passenger volume along the corridor. At the lowest passenger demand of around 5,000 passengers per direction per hour, automobile were the cheapest mode. The rail systems are the cost effective mode in high population densities, whilst bus systems have the lowest cost in the medium population density areas.

Then, Brand and Preston (2003) added total external cost to compare total social costs of 15 different PT modes including conventional bus, light rail and heavy rail system, and personal rapid transit at a strategic planning level. In the stand-alone model, total social costs of the 15 conventional and advanced PT technologies are calculated for a $12 \mathrm{~km}$ route corridor. Demand is assumed to be fixed, ranging from 1,000 to 200,000 daily passengers. Final outputs of the stand-alone model include average social costs, marginal operating costs and marginal external costs of congestion (in pence per passenger-km). The results show that the conventional bus has advantages for low daily demand of less than 40,000 passengers per day in a $12 \mathrm{~km}$ public transport route. Suburban heavy rail is the best mode when demand ranges from 40,000 to 88,000 passengers per day, whilst Underground has advantages when demand is higher than around 100,000 passengers per day. Based on the study of Brand and Preston (2003), Li and Preston (2015a) revised the speed-flow and waiting time equations to assess total socials costs of PT in different operating environments including mixed traffic, exclusive PT and grade-separated PT with respect to endogenous demand. 
In addition, Wang (2011) compares the full costs of seven passenger modes in large Chinese cities. The seven modes, which include heavy rail transit, light rail transit, arterial bus, bus rapid transit, expressway bus flier, automobiles and bicycles, are evaluated at varied traffic volumes in hypothetical radial and circumferential commuting corridors. Using detailed estimates of private and social costs, the full costs of each mode covering capital, operation, user time, safety and environmental costs, are minimized by optimizing infrastructure investment and operation plans. Firstly, PT vehicle size and train length are optimised within given ranges in addition to service frequency, and a maximum service frequency is applied to single-route operation of each PT mode. Secondly, road widths at different segments of the corridors are optimised in accordance with the traffic volume of the respective section. Finally, the operating speed of transit is estimated as a function of passenger volume. On all corridors and across different social discount rates scenarios, commuting by one or more forms of bus transit or bicycle is cheaper than automobile or rail in terms of average cost per passenger-km. However, in ring corridors, rail can be almost as cheap as bus under certain conditions, and bicycle can be less cost-effective than bus in some cases. Commuting by automobile is more expensive than bus transportation at low traffic volumes.

In general, these previous studies focused on automobile, conventional bus and PT technologies. However, there appears to be very little evidence on cost models for motorcycle, DRT (e.g. Uber and Taxi) and innovative PT technology (e.g. Monorail). As a result, this study extends the existing literature in two respects. Firstly, cost models for modes such as motorcycle, Uber/Taxi and Monorail, which have not previously been considered in the literature, are developed. Secondly, the ASC of four conventional and advanced PT technologies (conventional bus, BRT, Monorail and elevated Metro); two 
PRV modes (car and motorcycle); and two DRT modes (Taxi and Uber) are calculated for an urban corridor, and therefore compared to identify the most cost-effective transport mode at a strategic planning level.

\section{Transport social cost models}

This study develops the SCMs for one urban corridor rather than a complete network for fixed daily passenger demand. The main assumption is that only one transport mode uses the infrastructure facility of the whole corridor. Additionally, the daily passenger demand level is assumed to be exogenous, with a starting total daily passenger demand level of 1,000 and goes up with an increment of 1,000 total daily passengers until 700,000 pdd. The daily passenger demand is split into peak periods and off peak periods, which vary in different cities. Based on the PT cost functions by Brand and Preston (2003), DRT cost functions by Transport Research Partners (2016) and cost functions of PRV by Small and Verhoef (2007), the PT, PRV and DRT social cost models are developed. In combination, these studies have considered most of the cost elements of the total social costs for each type of transport mode. For example, Brand and Preston (2003) showed cost components for the PT social costs, Transport Research Partners (2016) analysed cost elements of Taxi while Small and Verhoef (2007) estimated cost components for automobile.

Generally, the total social costs (TSC) of each transport mode is sum of three main components including total operator costs - TOC (or infrastructure operator costs for PRV), total user costs - TUC (vehicle user cost for PRV) and total external costs (TEC):

$$
T S C=T O C+T U C+T E C
$$


For all modes, the TECs include accident cost, noise pollution cost, air pollution cost and climate change cost. Elements of TOCs and TUCs and their calculations are different for dissimilar modes. Firstly, the PT user costs cover walking time (WKT), waiting time (WTT) and in-vehicle time (IVT). Secondly, the TOCs for PRV cover operating costs for users, infrastructure costs, maintenance costs and parking costs. The TUCs for PRV consist of private vehicle capital costs, travel time and congested-related delay costs. Thirdly, the DRT operator costs cover capital cost; non-fuel operating cost; fuel cost; administrative cost; infrastructure costs and highway maintenance cost; and driver earnings. The DRT user costs cover walking time, in-vehicle time and waiting time.

In order to indicate the relationships between costs and demand levels, the equation for average social cost (ASC) is calculated as follows:

$$
A S C=T S C / P K M
$$

where,

PKM is total passenger-kilometres, calculated by the product of total passenger demand and average passenger journey length.

To estimate these social cost models, the main methods and key factors are detailed below.

(1) The average operating speed calculation in these cost models is very important as the quality of service highly depends on the operating speed of vehicles. Moreover, the speed is used to calculate most cost elements. Based on the speed equations of Small (1983), Brand and Preston (2003) and Li (2015), the average speed of each mode $\left(V_{\text {all }}\right)$ is calculated for two cases: traffic volume $(Q)$ is 
smaller than capacity $(C)$ and traffic volume is higher than capacity below. Note that the average operating speed cannot exceed the maximum speed.

$$
\begin{cases}V_{\text {all }}=V_{\text {NoCap }} & \text { if } Q<C \\ V_{\text {all }}=\frac{L}{\frac{L}{V_{\text {NoCap }}}+0.5 W\left(\frac{Q}{C}-1\right)} & \text { if } Q \geq C\end{cases}
$$

where,

$W$ is the peak period duration in hours. The default value can be 1 hour (Small 1983).

$L$ is the length of the study corridor in $\mathrm{Km}$.

For PT, $C$ is the infrastructure capacity, which is the maximum possible number of vehicles per lane (for road-based systems) or per track (for rail-based systems), and is calculated from the safety headway.

$Q$ is estimated by dividing passenger demand by occupancy of transport mode.

$V_{\text {NoCap }}$ is PT operating speed in $\mathrm{m} / \mathrm{s}$, which accounts for the stop density constraint without the capacity constraint (Brand and Preston 2003).

For motorcycle, based on the motorcycle equivalent unit (MCU) model of Nguyen, Sano, and Chu (2007), $V_{\text {NoCap }} \mathrm{kph}$ at a link of for one-lane per direction corridor is calculated as:

$$
V_{\text {NoCap }}=39.82-0.0011 * Q
$$

and for two-lane per direction corridor as (Chu, Sano, and Matsumoto 2005):

$$
V_{\text {NoCap }}=37.90-0.0018 * Q
$$


For car and DRT, the average link vehicle speed $V_{\text {NoCap }} \mathrm{kph}$ at flow $Q$

vehs/hour/3.65m lane is given by the following formula (Department for Transport 2014).

$$
V_{\text {NoCap }}=39.50-0.003 * Q
$$

(2) When the required data for estimation of external cost are not available in a low and middle income country, a Willingness To Pay (WTP) approach can be used in order to transfer from another country where the required data are available (Nellthorp, Bristow, and Day 2007, Gwilliam, Kojima, and Johnson 2004). The WTP estimate from the transfer country is calculated as:

$$
\mathrm{WTP}_{T}=W \mathrm{WP}_{\mathrm{s}} *\left(\text { Income }_{T} / \text { Incomes }^{\varepsilon}\right.
$$

where,

$W T P_{T}, W T P_{s}$ are WTP estimate from the transfer country (T) and study country (S) respectively ( $£$ );

Income, Incomes are Purchasing Power Parity (PPP) income per capita in the transfer country and study country correspondingly (£/year). A PPP is a price index, which provides a measure of price level differences across countries and should be used to convert expenditures in national currencies to a common currency (World Bank 2017).

$\varepsilon$ is the income elasticity of WTP - this can be used as 1.0 (Gwilliam, Kojima, and Johnson 2004, Bickel et al. 2005, Maibach et al. 2007).

(3) There is very little evidence on Uber costs, hence, the following assumptions are suggested. 
- Firstly, in the United States, 53\% of Uber driver-partners work 1-15 hours per week, $30 \%$ of them work 16-34 hours/week, $12 \%$ of them work 35-49 hours/week and 5\% of them work more than 50 hours/week (Hall and Krueger 2018). It is assumed that the average hours an Uber driver-partner works per week is the average of the mid-points of these values, which is estimated at around 19.28 hours per week. Moreover, Hall and Krueger (2018) stated that an Uber driver would travel about 35,000 miles in 2,000 hours of professional driving. Hence, a speed of 17.5 miles an hour is used to estimate the annual distance that an Uber driver-partner drives (around 17,544 miles per year). This compares with an average for cars in the United States of 12,375 miles in 2005 (Small and Verhoef 2007). Uber vehicle capital cost depends on the extent to which Uber miles are additional and the extent to which depreciation is mileagerelated. It is assumed that all Uber miles are additional and that capital costs are annualised using the Capital Recovery Factor and apportioned using mileage. Therefore, in broad terms, the vehicle capital cost of Uber can be allocated 41.4 \% for personal purposes and 58.6 \% for Uber rides. This means Uber vehicle capital cost is estimated as $58.6 \%$ of the vehicle capital cost of a private passenger car.

- Secondly, Uber drivers using the driver app are charged the Uber Fee as a percentage of each trip fare. If surge pricing applies to a trip, the Uber Fee percentage is also deducted from the surge amount. The Uber Fee helps cover costs including technology, development of app features, marketing, and payment processing for driver-partners (Uber 2018). The Uber Fee varies by countries and types of Uber. Indeed, Uber receives from 5\% to $20 \%$ of the trip price, with the rest for the driver (Schneider 2017). Mostly, that number is 20\%, 
for example, as in the UK and for Uber Black in Netherland, whilst it is $25 \%$ in

Vietnam. In this study, the Uber Fee is assumed as 25\% of Uber driver earnings before vehicle expenses.

- Thirdly, it is difficult to obtain data for estimating directly Uber driver earnings. Hence, an indirect estimation from Taxi driver earnings is considered, because data on Taxi driver wages can be available. Based on the results of the study by Hall and Krueger (2018), it is assumed that the taxi driver wages (after vehicle expenses) are as the same as the hourly earnings of Uber driver-partners (after vehicle expenses). Hall and Krueger (2018) also find that the Uber driverpartners wages after vehicle expenses are around 2/3 of the wages before vehicle expenses and it is assumed this also applies to taxi drivers.

To conclude, by calculating the ASC per passenger-kilometre, the most costeffective transport mode for the distinct demand level can be identified. The SCMs calculate operator cost, user cost, external cost and hence social cost and average social cost for each transport mode. Figure 1 shows the operating procedure of the three social cost models. The vehicle parameters and default values in these social cost models are shown in Section 4. Two example calculations for the one exclusive motorcycle lane option and the elevated Metro option are illustrated in Table 5 and Table 6.

\section{Case study}

LMICs are of particular interest to this study as most of the previous studies on cost models have been built for HICs, whilst a few additional studies has focused on China. Moreover, there appears to be very little evidence on cost models for motorcycle and DRT (e.g. Uber), which are important transport modes in many LMICs. Hanoi, the capital of Vietnam, is then selected as a case study for the following reasons. Firstly, 
Vietnam is determined as a lower middle income country with a GNI per capita of US\$ 2,400 in 2018 (World Bank 2019). Secondly, the characteristics of the transport system in Hanoi can be found in many cities in LMICs, where a range of transport modes share the facilities such as conventional bus, car, motorcycle, Uber and Taxi. Thirdly, in conjunction with existing conventional bus systems, several new PT projects have been developed in Hanoi such as BRT and urban rail transit.

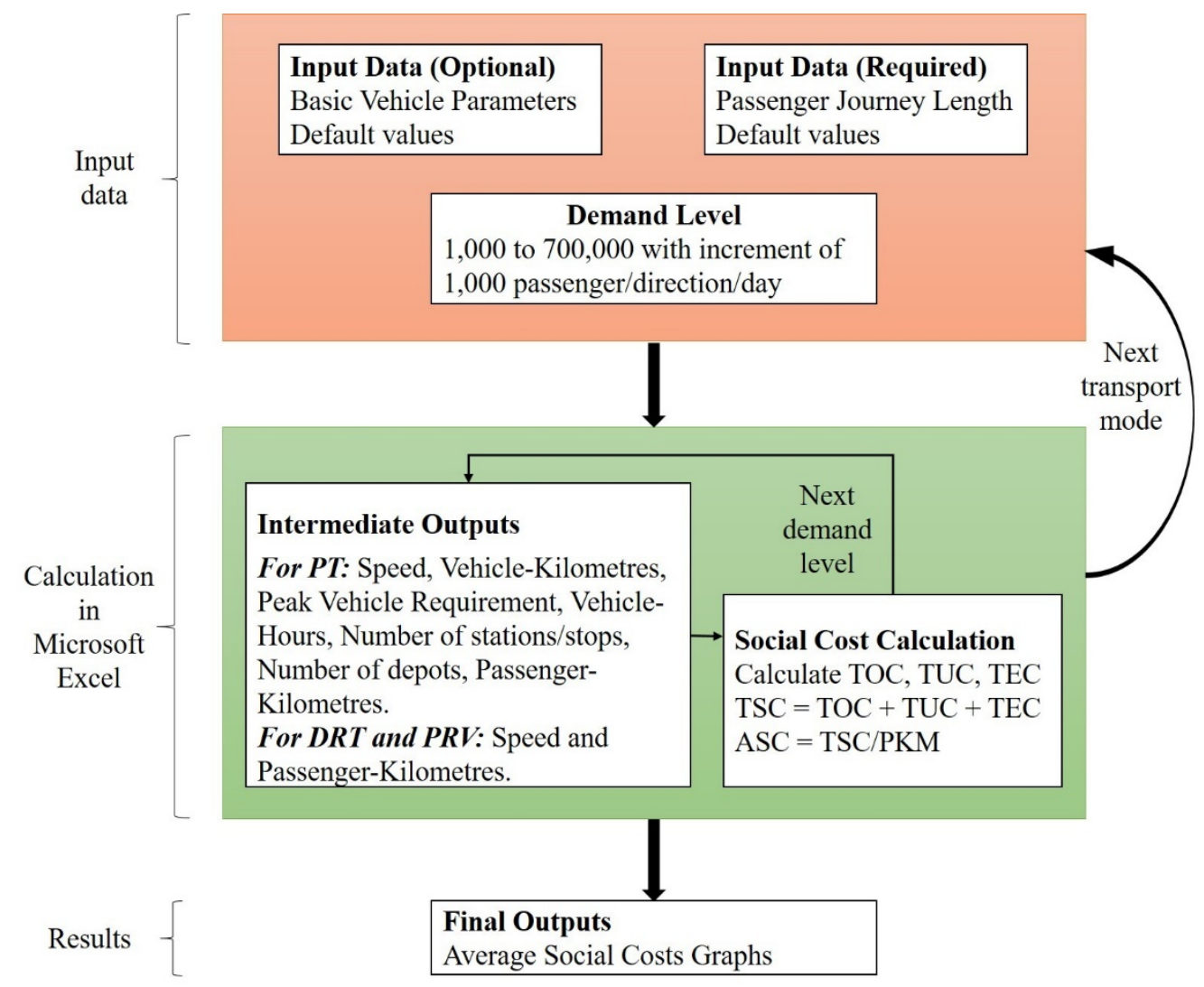

Figure 1 Procedure of the three social cost models

Basic input parameters in the three social cost models are adapted from secondary data provided by the People’s Committee of Hanoi (PCH), Transport Engineering Design Incorporated (TEDI), Hanoi Transport Management and Operation Centre (TRAMOC), Hanoi Metro Company (HMC), T\&D Vietnam Highway Consultancy Companies (T\&D) and TTS Group. Some of these parameters are shown in Table 5 and Table 6. Considering the price dissimilarity concerning labour costs and 
material costs between the UK and Vietnam, the PPP rate from the World Bank (WB) is used. The PPP rate in 2015 for the UK was 0.69 while that number for Vietnam was 7,576.25 (World Bank 2015b). Hence, a factor of $0.00009(0.69 / 7,576.25)$ is used to convert the Vietnamese currency (VND) into the British currency (GBP). The main input parameters are illustrated below and all prices are calculated in GBP in 2015 prices.

Firstly, eight transport modes are modelled in this study. The characteristics, default unit capital costs and life expectancies of these modes are shown in Table 1. Assuming that only one transport mode uses the infrastructure facility, the infrastructure costs of road-based modes, excluding the costs of PT stops and depots, are the same. Capital costs must to be converted to an annual basis by using the Capital Recovery Factor (CRF), which is a function of the economic life expectancy and the discount rate (Rogers and Duffy 2012). The discount rate (DR) for capital investment is set at $12 \%$ for the Hanoi case study (World Bank 2015a). To illustrate how the cost comparisons are impacted by the DR, a sensitivity analysis is implemented with other two different DRs (8\% and 16\%). Additionally, due to the available data in the Hanoi case study, the Fully Allocated Costs (FAC) model is chosen to calculate the total operator costs of PT. The PT operator costs include vehicle operating and maintenance costs; and capital investment costs. Vehicle operating and maintenance costs are assigned to the allocation variables such as Vehicle-Hours, Vehicle-Distance and Peak Vehicle. The infrastructure capital costs are allocated to Track/Lane Distance, number of Stops/Stations and number of Depots. Table 2 shows unit PT operator costs. 
Table 1 Vehicle characteristics, default unit capital costs and life expectancies

\begin{tabular}{|c|c|c|c|c|c|c|c|c|}
\hline Transport modes & $\begin{array}{l}\text { Person } \\
\text { capacity } \\
\text { (pax) }\end{array}$ & $\begin{array}{l}\text { Occupancy }^{1} \\
\text { (pax) }\end{array}$ & $\begin{array}{l}\text { Vehicle } \\
\text { length } \\
\text { (m) }\end{array}$ & $\begin{array}{c}\text { Max. } \\
\text { speed } \\
(\mathrm{km} / \mathrm{h})\end{array}$ & $\begin{array}{c}\text { Infrastructure } \\
\text { capacity } \\
\text { (vehicles/h) }\end{array}$ & $\begin{array}{l}\text { Vehicle } \\
\text { costs ( } £ \\
\text { thousand } \\
\text { /vehicle) }\end{array}$ & $\begin{array}{c}\text { Life } \\
\text { expectancies in } \\
\text { years (Vehicle/ } \\
\text { Infrastructure) }\end{array}$ & $\begin{array}{c}\text { Infrastructure } \\
\text { costs }^{2} \\
\text { (£ million } / \mathrm{km})\end{array}$ \\
\hline Conventional bus $^{3}$ & 80 & 33 & 12 & 55 & $225(340)^{4}$ & 182.1 & $20 / 20$ & $9.0(15.0)^{4}$ \\
\hline $\mathrm{BRT}^{5}$ & 90 & 41 & 12.3 & 60 & 240 & 455.4 & $20 / 20$ & 9.0 \\
\hline Elevated Metro ${ }^{6}$ (4-car unit) & 820 & 287 & 80 & 80 & 138 & $3,045.3$ & $25 / 50$ & - \\
\hline Monorail $^{7}$ (4-car unit) & 360 & 126 & 50 & 80 & 156 & 2,000 & $25 / 50$ & - \\
\hline Passenger car $^{8}$ & 5 & 1.57 & - & 55 & 1,800 & 15.6 & $20 / 20$ & $9.0(15.0)^{4}$ \\
\hline Motorcycle $^{8}$ (125cc) & 2 & 1.22 & - & 50 & $\begin{array}{c}5,000 \\
(9,000)^{4}\end{array}$ & 1.5 & $13 / 20$ & $9.0(15.0)^{4}$ \\
\hline $\operatorname{Taxi}^{9}$ & 5 & 1.57 & - & 55 & 1,800 & 17.3 & $20 / 20$ & 9.0 \\
\hline Uber & 5 & 1.57 & - & 55 & 1,800 & 7.8 & $20 / 20$ & 9.0 \\
\hline
\end{tabular}

Notes:

All costs are in 2015 prices.

${ }^{1}$ Monorail and Metro occupancy rates are assumed as 35\% of vehicle person capacity

(European Environment Agency 2015). Motorcycle, passenger car and bus occupancies are shown in the report of Transport Engineering Design Incorporated (2013). BRT occupancy in 2017 was provided by TRAMOC. It is assumed that occupancies of Taxi/Uber (excluding the driver) and car (including the driver) are the same.

${ }^{2}$ Based on data provided from the PCH and T\&D.

${ }^{3}$ Based on the report of Hanoi Transport Management and Operation Centre (2011).

${ }^{4}$ Values in bracket () are for the two-lane per direction corridor.

${ }^{5}$ Based on the report of Hanoi Transport Management and Operation Centre (2011).

${ }^{6}$ Based on data on URT line 1, 2A and 3, which are provided by Hanoi Metro Company.

${ }^{7}$ Based on the study of DMJM Harris (2001).

${ }^{8}$ Based on the studies by Bray and Holyoak (2015) and Nguyen, Sano, and Chu (2007).

${ }^{9}$ Taxi vehicle cost is adapted from data showed on a Taxi Group website (Taxi Group 2018).

Other parameters are assumed as those numbers of car.

There are few empirical estimates of value of time (VOT) in Vietnamese cities, but evidence on the relationship between VOT and travellers' income is reasonably consistent (Wardman, Chintakayala, and de Jong 2016). It seems to be concluded that the value of time for personal journeys varies widely by circumstance, usually between $20 \%$ and $90 \%$ of the gross wage rate and averaging around 50\% (Small and Verhoef 2007). However, due to available data on modal splits in Hanoi in 2010, transferring of value of time in the UK to Vietnam is suggested. The comparable value of time in the

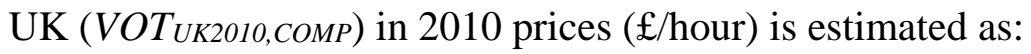


where,

VOTUK2010,WT, VOTUK2010,C, VOTUK2010,o are value of working time, by

commuting and non-working time in the UK respectively, in 2010 prices (£/hour);

$P_{W T}, P_{C}, P_{O}$ are proportion of travellers in course of work, travellers commuting and travellers for other purposes in the Hanoi travel survey (\%);

Then, value of time in Vietnam (VOTVN2010) in 2010 prices ( $£ /$ hour) is calculated as follows:

$$
V_{V O T} T_{V N 2010}=V_{U O T} T_{U K 2010, C O M P} * I_{N C O M E_{V N 2010}} / I_{N C O M E_{U K 2010}}
$$

where,

INCOMEVN2010, INCOME ${ }_{U K 2010}$ are mean income in Vietnam and the UK in 2010 correspondingly (PPP £);

Using data on modal share by purpose of journey (Transport Engineering Design Incorporated 2013), GDP deflator and values of time in the UK in WebTAG, the value of IVT for car in Vietnam (in 2015 prices) is calculated as 0.77 ( $£$ /hour). In addition, based on the study of Wardman, Chintakayala, and de Jong (2016), it is assumed that the values of IVT by mode are as follows. Those numbers for PT and Uber/Taxi are the same, which are equal to 0.7 times than the value for car, while the number for motorcycle is twice than the value of IVT for car.

The results of unit external costs by different modes for the Hanoi case study are estimated by using findings of several empirical studies by Sansom et al. (2001), Chen et al. (2003), Tsai et al. (2005), Maibach et al. (2007), Wang (2011), Vu et al. (2013), Li and Preston (2015b), Manoratna, Kawata, and Yoshida (2017) and WebTAG. In order to take into account of the vehicle occupancy, unit external costs of each mode are 
transferred from pence/vehicle-distance into pence/passenger-distance. The central values are used rather than low and high values in this study, which are shown in Table 3.

Table 2 Default unit PT operator costs

\begin{tabular}{|l|l|l|l|l|l|l|}
\hline Cost components & $\begin{array}{c}\text { Vehicle } \\
\text { Hours }\end{array}$ & $\begin{array}{c}\text { Vehicle } \\
\text { Distance }\end{array}$ & $\begin{array}{c}\text { Peak Vehicle } \\
\text { Requirement }\end{array}$ & $\begin{array}{c}\text { Track/lane } \\
\text { Distance }\end{array}$ & $\begin{array}{c}\text { Station } \\
\text { / Stop }\end{array}$ & Depot \\
\hline Units & $\begin{array}{c}\text { VH per } \\
\text { VKM }\end{array}$ & $\begin{array}{c}£ 2015 \text { per } \\
\text { pa }\end{array}$ & $\begin{array}{c}£ 2015 \text { per } \\
\text { track/lane } \\
\text { distance pa }\end{array}$ & $\begin{array}{c}£ 2015 \text { per } \\
\text { Station/stop pa }\end{array}$ & $\begin{array}{c}£ 2015 \text { per } \\
\text { depot pa }\end{array}$ \\
\hline Conventional bus $^{1}$ & 21.14 & 0.55 & $15,384.70$ & $1,204,909.02$ & 182.89 & $60,964.43$ \\
\hline BRT $^{2}$ & 17.66 & 0.55 & $62,355.85$ & $1,204,909.02$ & $109,948.03$ & $60,964.43$ \\
\hline Elevated Metro $^{3}$ & 444.42 & 7.87 & $442,502.85$ & $1,836,945.18$ & $2,243,595.49$ & $5,483,418.43$ \\
\hline Monorail $^{4}$ & 331.09 & 5.51 & $178,499.96$ & \multicolumn{3}{|c|}{$1,806,249.95$} \\
\hline
\end{tabular}

Notes:

${ }^{1}$ Based on data provided by TRAMOC and the report of Hanoi Transport Management and Operation Centre (2011).

${ }^{2}$ Based on the report of Hanoi Transport Management and Operation Centre (2011).

${ }^{3}$ Based on data on URT line 1, 2A and 3, which are provided by Hanoi Metro Company.

${ }^{4}$ Based on the study of DMJM Harris (2001). The study summarised characteristics and parameters of Bombardier technology as follows. The capital construction cost is around \$50 million per track mile. Assume that Annual Vehicle-Hours and Vehicle-Kilometre are equal to $70 \%$ of Metro Vehicle-Hours and Vehicle-Kilometre. Infrastructure costs cover capital costs of track, station and depot, which are per Route Km.

Based on results of a traffic survey in 2016 provided by the TTS Group, data on passenger split by time at several roads in Hanoi are collated. The core operating day time services are assumed to be from 06:00 to 21:00 and daily passenger demand is split into the four periods including the peak hours (2 hours), peak periods (3 hours), mid-day off-peak (7 hours) and early morning-late evening off-peak (3 hours), which are described in Table 4. 
Table 3 Default external unit costs by impact category in the Hanoi case study, 2015 prices

\begin{tabular}{|l|c|c|c|c|}
\hline Transport modes & $\begin{array}{c}\text { Air } \\
\text { pollution } \\
(\mathrm{p} / \mathrm{pax} \mathrm{km)}\end{array}$ & $\begin{array}{c}\text { Noise } \\
\text { pollution } \\
(\mathrm{p} / \mathrm{pax} \mathrm{km})\end{array}$ & $\begin{array}{c}\text { Climate change } \\
(\mathrm{p} / \mathrm{pax} \mathrm{km})\end{array}$ & $\begin{array}{c}\text { Accidents cost } \\
(\mathrm{p} / \mathrm{pax} \mathrm{km})\end{array}$ \\
\hline Bus & $0.10^{1}$ & $0.04^{1}$ & $0.0089^{1}$ & $0.01^{1}$ \\
\hline BRT & $0.10^{1}$ & $0.04^{1}$ & $0.0078^{1}$ & $0.01^{1}$ \\
\hline Monorail & $0.0008^{1}$ & $0.0014^{1}$ & $0.0009^{2}$ & $0.0001^{3}$ \\
\hline Elevated Metro & $0.0008^{1}$ & $0.0017^{1}$ & $0.0005^{1}$ & $0.0001^{3}$ \\
\hline Car/Uber/Taxi & $0.11^{4}$ & $0.06^{4}$ & $0.06^{4}$ & $0.10^{4}$ \\
\hline Motorcycle & $0.12^{5}$ & $0.15^{6}$ & $0.03^{7}$ & $1.92^{8}$ \\
\hline
\end{tabular}

Sources: ${ }^{4}$ Sansom et al. (2001), ${ }^{5}$ Chen et al. (2003), ${ }^{5,7}$ Tsai et al. (2005), ${ }^{5,6,8}$ Maibach

et al. (2007), ${ }^{3}$ Wang (2011), ${ }^{5}$ Vu et al. (2013), ${ }^{1}$ Li and Preston (2015b), ${ }^{2}$ Manoratna,

Kawata, and Yoshida (2017) and ${ }^{2,7}$ WebTAG.

Notes:

- External costs of Uber and Taxi are assumed as the same as car.

- External costs of BRT are assumed as the same as a single bus on busway.

- Air and noise pollution costs of Monorail are assumed as those of modern light rail.

- Air pollution, noise pollution and climate change costs of elevated Metro are assumed as the same as suburban heavy rail.

- Assume that accidents cost of Monorail and elevated Metro are the same.

Table 4 Passenger demand split into different times in the Hanoi case study

\begin{tabular}{|l|c|c|c|c|}
\hline \multicolumn{1}{|c|}{ Period } & Time-time & $\begin{array}{c}\text { Period } \\
\text { duration } \\
\text { (hours) }\end{array}$ & $\begin{array}{c}\text { Split rate for } \\
\text { one hour } \\
\text { period }\end{array}$ & $\begin{array}{c}\text { Daily } \\
\text { split }\end{array}$ \\
\hline Early morning off-peak & $6: 00-7: 00$ & 1 & $4.0 \%$ & $4.0 \%$ \\
\hline Morning peak hour & $7: 00-8: 00$ & 1 & $10.0 \%$ & $10.0 \%$ \\
\hline Morning peak period & $8: 00-9: 00$ & 1 & $7.5 \%$ & $7.5 \%$ \\
\hline Mid-day off-peak & $9: 00-16: 00$ & 7 & $6.5 \%$ & $45.5 \%$ \\
\hline Afternoon peak period & $16: 00-17: 00$ & 1 & $7.5 \%$ & $7.5 \%$ \\
\hline Afternoon peak hour & $17: 00-18: 00$ & 1 & $10.0 \%$ & $10.0 \%$ \\
\hline Evening peak period & $18: 00-19: 00$ & 1 & $7.5 \%$ & $7.5 \%$ \\
\hline Late evening off-peak & $19: 00-21: 00$ & 2 & $4.0 \%$ & $8.0 \%$ \\
\hline
\end{tabular}

Source: data collated from the TTS Group. 


\section{Results}

\subsection{One-lane per direction corridor}

To compare the ASCs of different transport modes, the PT, PRV and DRT social cost models are calculated for a 1-lane (per direction) corridor with the length of $7 \mathrm{~km}$ and average passenger journey length of $4 \mathrm{~km}$. Figure 2 shows the results of the ASCs of PT, PRV and DRT modes for 1-lane (per direction) corridor in the Hanoi case study.

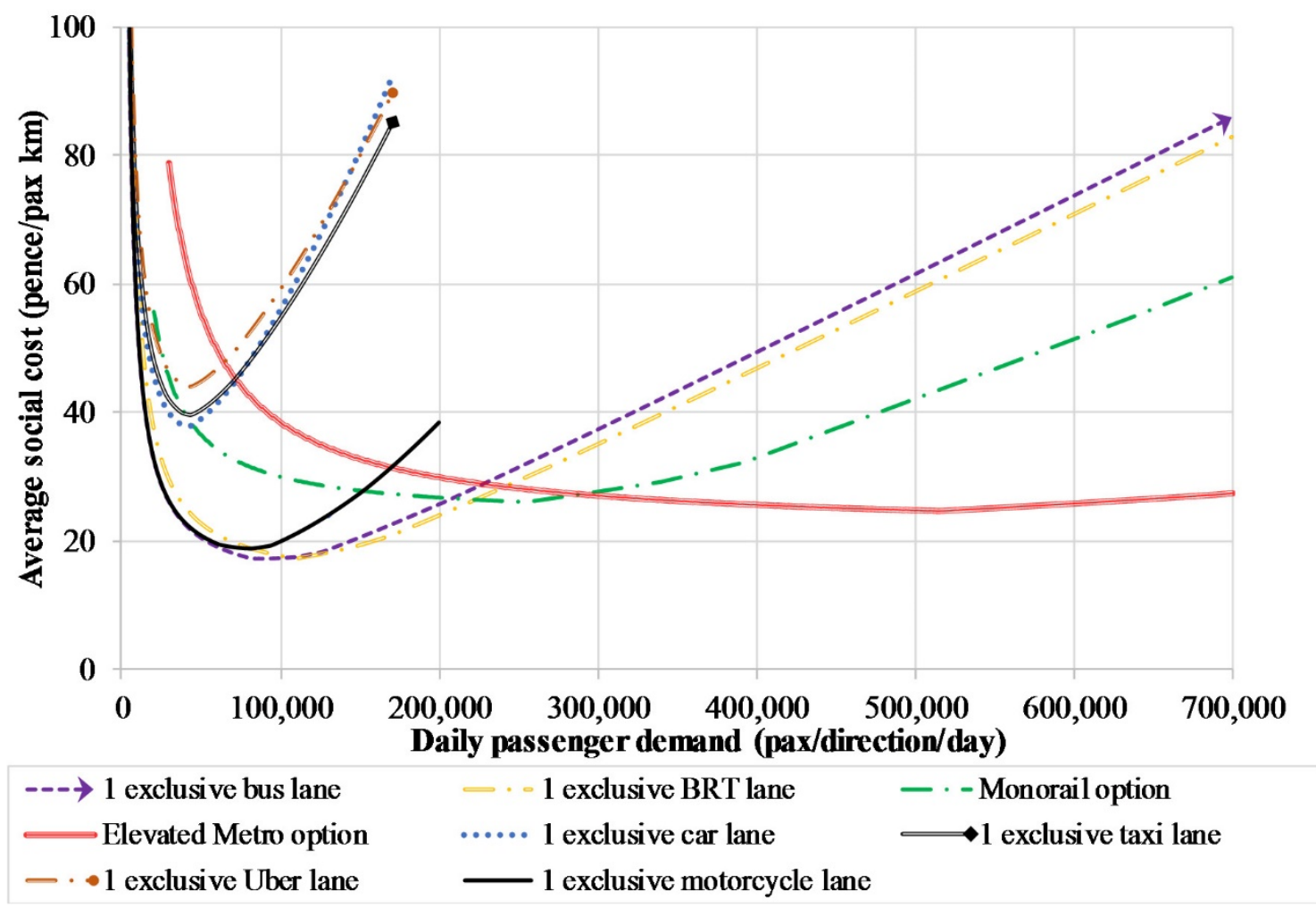

Figure 2 The ASC as a function of demand for 1-lane (per direction) divided corridor, 2015 prices

As can be seen from Figure 2, the relationships between the ASC and demand level for all transport modes are shown as U-shape curves. The explanation can be that while fixed costs per passenger are high at low demand levels, these reduce as they are spread across higher levels of demand. By contrast, route capacity constraints have a significant impact on speeds, and therefore costs, at higher demand levels. When 
demand reaches route capacity, speeds decrease dramatically. In addition, Figure 2 shows that the slopes of the curves for PRV and DRT are much steeper than those for PT due to low person occupancy of PRV and DRT.

Figure 2 shows that when the daily demand levels range from 1,000 to 35,000 pdd, the ASC of the motorcycle option is the smallest. The reasons for this might be:

- Motorcycle speed is quite high at low demands due to small size and flexibility, as well as motorcyclists do not appear to stop during their journeys.

- Operating costs of motorcycle is lower than those costs of bus-based technologies, which seems to have advantages at low demand levels.

However, the ASC of the motorcycle option is only slightly lower than the ASC of the conventional bus option at low demand levels, because infrastructure costs for road-based options including motorcycle, car, Uber/Taxi and conventional bus are the same, and this accounts for a major portion of total social costs at low demand levels. When the daily demand is from 35,000 to 107,000 pdd, conventional bus shows the smallest ASC. When compared to motorcycle, the significantly higher person capacity of bus is an advantage. Moreover, compared to rail-based technologies, infrastructure costs and operator costs of bus-based technologies are significantly smaller. This seems to be a benefit for conventional bus at low and medium demand levels. BRT is the best mode for a daily demand range of between 107,000 and 220,000 pdd although the ASCs of BRT and bus can be similar due to insignificant differences in vehicle capital costs and person capacity of vehicles. This can be reasonably consistent with several successful BRT systems in the world such as Transmilenio in Bogota, Sao Paulo, Porto Alegre, and Curitiba with 20,000 passengers per hour per direction (Hensher and Golob 2008). Indeed, the peak hour demand is assumed as $10 \%$ of the daily demand in this 
study, which is shown in Table 4. Obviously, conventional bus in mixed traffic with private transport modes would change this similarity dramatically as conventional bus would not be dedicated anymore and, consequently, there would be lower average speed and higher waiting and in-vehicle time for bus users.

When daily demand level is between 220,000 and 290,000 pdd, the ASC of Monorail is the lowest while Metro has advantages with demand higher than 290,000 pdd. This might prove the BTS Sky Train in Bangkok, Thailand is a successful elevated Metro line with average March weekday ridership of 749,180 passengers in both direction in 2018 (Bangkok Mass Transit System Public Company Limited 2018). The higher capacity than bus-based technologies, and the lower capital investment for vehicles and infrastructure than Metro, make Monorail achieve the lowest ASC within the demand level from 220,000 pdd to 290,000 pdd.

The ASC for car and Taxi/Uber are similar if their occupancy are the same. The ASCs of these options are considerably higher than those numbers for conventional bus, BRT and motorcycle. The reasons for this might be:

- Compared to motorcycle with the similar occupancy, capital vehicle costs for car, Taxi and Uber are much higher, as well as greater taxes for these vehicles. Indeed, they include a value added tax (VAT) of 10 percent; an import duty of between 15 percent and 60 percent; a special consumption tax that ranges from 45 percent to 60 percent (depending on engine capacity); and an ownership registration tax and a one-off first time registration fee that are together a little over 20 percent (Bray and Holyoak 2015). A sensitivity test was performed to investigate the differences if these taxes are not included in the SCMs. Based on the results of the sensitivity test, the curves for car, Taxi and Uber in Figure 2 shift downwards for around 7 pence/pax km. 
- Compared to PT modes, lower occupancy is a drawback whist these modes appear to have advantage of minor higher average speed.

\subsection{Two-lane per direction road-based corridor}

These comparisons above are measured for the one-lane per direction corridor.

However, this seems to be insufficient for road-based arterials in urban areas, where there are normally more than one lane per direction. In addition, buses are not allowed to overtake in the one-lane per direction corridor, which can cause congestion rapidly when demand increases and reaches capacity, whilst motorcycles can overtake easily in the one-lane per direction corridor. As a result, a two-lane per direction corridor is considered for motorcycle, car and bus options, and is then compared with rail-based systems. The results of ASCs of these options are shown in Figure 3.

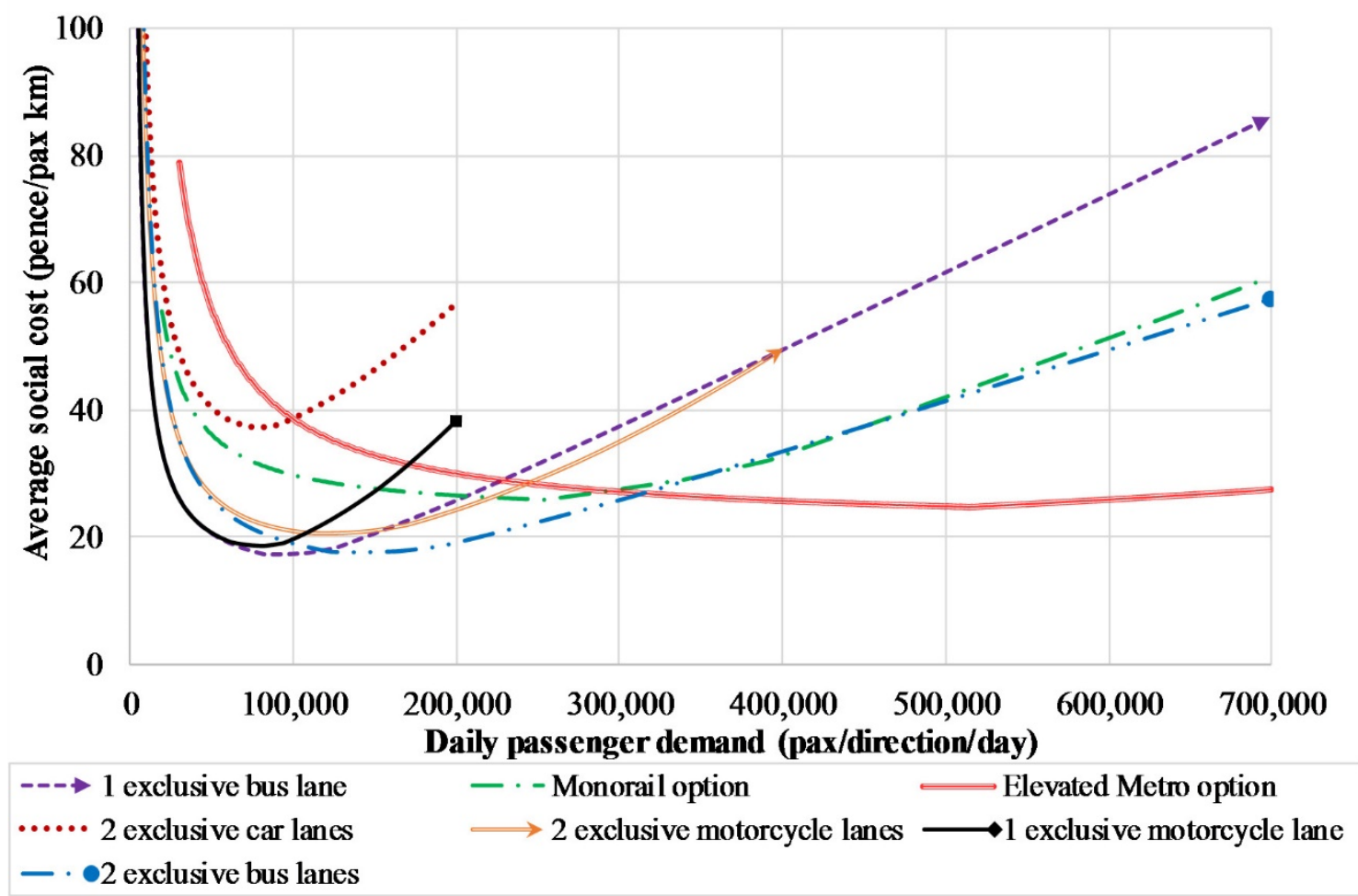

Figure 3 ASCs of different road-based and rail-based modes, DR=12\%, 2015 prices 
Figure 3 describes that when one more lane per direction for motorcycle or bus is expanded, the curves for motorcycle or bus shift to the right side. This means that higher demand levels can be supplied at the same ASC when Right of Way (RoW) is expanded. Therefore, an expansion of RoW can be a feasible option when the demand levels of one single mode increase. However, the expanding option should be compared to other options for different modes. This can be illustrated below.

The one exclusive motorcycle lane per direction corridor is the best option at demand levels below 35,000 pdd. When demand levels increase, expanding one motorcycle lane per direction does not appear to be appropriate because this option cannot be as competitive as the one exclusive bus lane or two exclusive bus lanes per direction options. When demand is higher than 220,000 pdd, expanding one bus lane per direction can be better than Monorail. However, when demand reaches 315,000 pdd and above, bus-based technologies are not sufficient. The reason for that is that the costs are extremely high as the number of vehicles required becomes more than the infrastructure capacity and congestion causes the user costs to be much higher. Hence, Metro is the most appropriate option for those high demand levels due to high person capacity.

To analyse how the cost comparisons are affected by the DR, Figure 3, Figure 4 and Figure 5 show the results under three dissimilar DRs. In general, when the DR rises from $8 \%$ to $16 \%$, the cost curves of all modes shift upward due to increases in infrastructure costs and capital vehicle costs. Moreover, the cost curves of car with low occupancy move upward at a faster rate than those of other modes. Additionally, the costs of the more capital-intensive elevated Metro is the most sensitive to changes in the DRs, particularly significant changes occur at low demand levels. However, the options having the minimum ASC are broadly unchanged for the range of demand levels studied. There are only insignificant changes at critical points of demand levels, where 
the lowest ASC switches from one mode to another mode. The changes from the two bus lanes per direction option to the elevated Metro option is an example. Critical points of demands levels are at 305,000; 315,000 and 320,000 pdd with respect to the DRs of $8 \%, 12 \%$ and $16 \%$ respectively. To conclude, this sensitivity test demonstrates that DRs do not materially impact on the basic results of the analysis.

The results show that external costs account for small proportion of total social costs for all modes, compared to the operator and user costs. This is consistent to the study of Wang (2011). Most external unit costs for all modes are less than $0.1 \mathrm{p} / \mathrm{pax} \mathrm{km}$ (except the accident costs of motorcycle), which are minor components of the ASC. Hence, a sensitivity analysis for external costs can be ignored in this study.

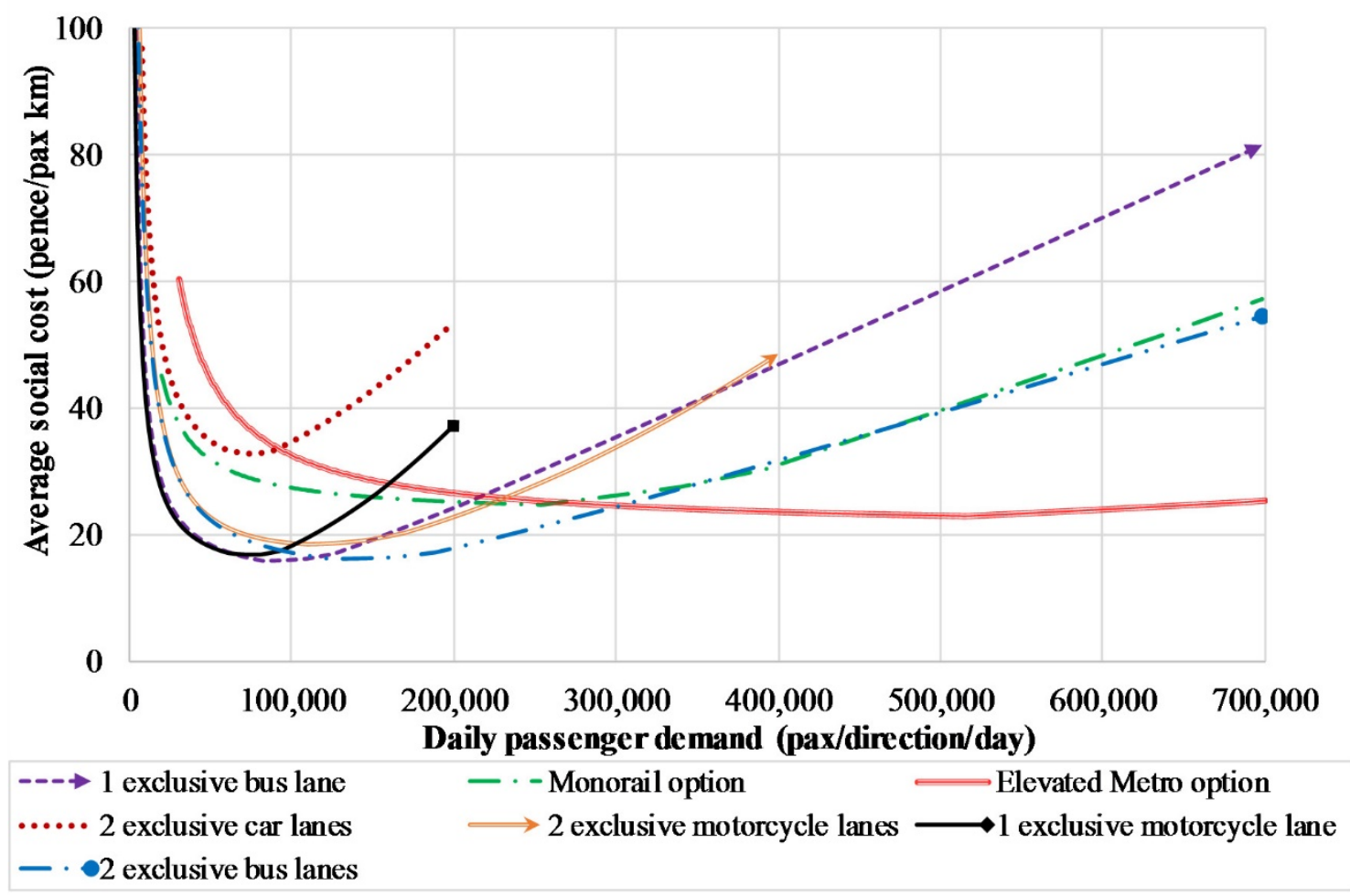

Figure 4 ASCs of different road-based and rail-based modes, DR=8\%, 2015 prices 


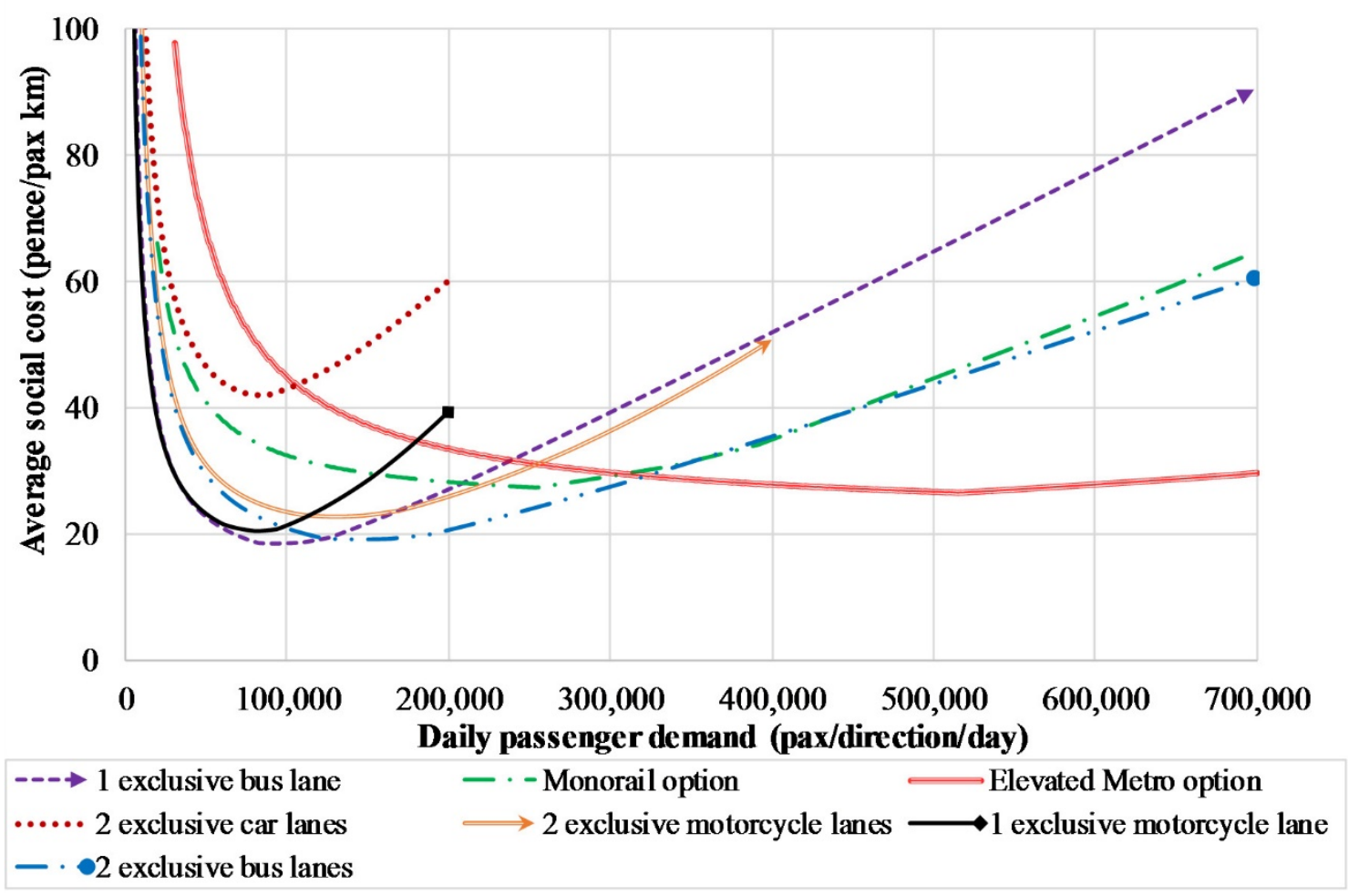

Figure 5 ASCs of different road-based and rail-based modes, DR=16\%, 2015 prices

\section{Conclusion and future work/discussion}

This study introduced the social cost models for motorcycle and DRT including Uber and Taxi as well as developed the cost models for car and PT technologies based on the previous studies. Through comparing the average social cost of four PT technologies, two PRV modes and two DRT modes for an urban corridor in the Hanoi case study, this paper identifies the most cost-effective transport mode with respect to different passenger demand levels at a strategic planning level. Additionally, with optional inputs and the flexibility of the cost functions, the social cost models are able to be modified to suit other local conditions.

Transport planners and decision makers in LMICs can draw the following from the Hanoi case study depending on demand levels. 
- First, car cannot be the best social option at any demand levels due to the higher ASC. With service quality advantages and great support by technology companies, Uber and Taxi are still expensive and, therefore might not be chosen. The main drawback of these modes is the low occupancy of around 1.57 passengers. To some extent, this supports the policy adopted by some cities to promote car sharing and UberPool to increase the occupancy. "Three-in-one” policy in Jakarta, Indonesia is an example. All private cars on two major roads were required to carry at least three passengers during peak hours in Jakarta. This policy was abandoned in April 2016. However, Hanna, Kreindler, and Olken (2017) prove that this policy may improve traffic conditions by showing increases in delays in the peak hours after ending the policy.

- Second, motorcycle is cheapest at low demand levels due to small size and flexibility advantages and hence low travel time. This may prove that motorcycle dominates and may be sufficient in many small and medium cities in LMICs. However, conventional bus seems to be an alternative because the ASC of conventional bus is only slightly higher than the ASC of motorcycle. It should be noted that demand is assumed to be fixed. In reality, all other things being equal, we might still expect different modes to have dissimilar level of usage due to different individual preferences and capabilities - in particular not everyone can ride a motorcycle. When demand levels increase, and especially when the capacity of motorcycle infrastructure is exceeded, this mode does not have advantages any more due to a dramatic decrease in speed. Expanding one more motorcycle lane per direction is not as competitive as dedicated bus-based technologies. Conventional bus or BRT are the best modes for a daily demand range of between 35,000 and 220,000 pdd. 
- Third, for big cities where demand levels are greater, expanding one more exclusive bus lane per direction and rail-based technologies could be compared to choose the cost-effective mode. For example, when the daily demand level is greater than 220,000, bus option with expansion of ROW and Monorail can be two competitive alternatives. For the Hanoi case study, the expanding option might be better. However, at the highest demand level (above around 315,000 pdd), elevated Metro seems the best option, given its high person capacity.

It is necessary to note the limitations of this study and then illustrate the future work.

- Firstly, as a strategic level model, it only considers an isolated corridor without any interaction with the whole network, as well as assuming only one transport mode is operated in this corridor at a given time. This assumption is clearly not true for mixed traffic environments where several transport modes share the infrastructure facilities such as bus, motorcycle and car. Hence, a cost model for mixed transport is being developed based on the three social cost models of single modes. In the mixed transport cost model, the average operating speed of each mode in the mixed traffic environment will be reviewed because this intermediate output is essential. Moreover, infrastructure costs will need to be allocated to transport modes sharing the facilities. This can overcome a limitation which assumes the same infrastructure costs for road-based options.

- Secondly, the daily passenger demand level in these models is assumed to be exogenous. Based on the study of Li and Preston (2015a), endogenous demand will be improved by using the incremental arc elasticity of demand with respect to passenger waiting time and in-vehicle time. 
- Thirdly, these comparative cost models do not incorporate a suitable demand model (such as the nested incremental logit model), which means the preferences of users for alternative transport modes cannot be taken into account in the study. Hence, a suitable transport demand model will be implemented in the future.

- Fourthly, this study does not include all modes in urban areas such as bicycle, electric bicycle, electric motorcycle or taxi-motorcycle.

References

Bangkok Mass Transit System Public Company Limited. 2018. Lift Up Your Life. Annual Report 2017-2018. Bangkok: Bangkok Mass Transit System Public Company Limited.

Bickel, Peter, Arnaud Burgess, Alistair Hunt, James Laird, Christoph Lieb, Gunnar Lindberg, and Thomas Odgaard. 2005. Developing Harmonised European Approaches for Transport Costing and Project Assessment Deliverable 2 'Stateof-the-art in Project Assessment'. Stuttgart: IER, University of Stuttgart.

Brand, Christian, and John Preston. 2003. The Software Tool: Specification and Case Study Validation. TSU Working Paper (Ref. 948). Oxford: Transport Studies Unit, University of Oxford.

Bray, David, and Nicholas Holyoak. 2015. "Motorcycles in Developing Asian Cities: A Case Study of Hanoi." Paper presented at the 37th Australasian Transport Research Forum (ATRF), Sydney, New South Wales, Australia, September 30 October 2.

Chang, Hsin-Li, and Tsu-Hurng Yeh. 2006. "Regional Motorcycle Age and Emissions Inspection Performance: A Cox Regression Analysis." Transportation Research Part D: Transport and Environment 11 (5):324-332. doi:

10.1016/j.trd.2006.06.004.

Chen, Kangshin, Wencheng Wang, H. M. Chen, C. F. Lin, H. C. Hsu, Jenho Kao, and M. T. Hu. 2003. "Motorcycle Emissions and Fuel Consumption in Urban and Rural Driving Conditions." Science of The Total Environment 312 (1-3):113122. doi: 10.1016/s0048-9697(03)00196-7. 
Chu, Cong M., Kazushi Sano, and Shoji Matsumoto. 2005. "The Speed, Flow and Headway Analyses of Motorcycle Traffic." Journal of the Eastern Asia Society for Transportation Studies 6:1496-1508.

Department for Transport. 2014. "TAG UNIT M3.1 Highway Assignment Modelling." Department for Transport, accessed 24 June 2018.

https://assets.publishing.service.gov.uk/government/uploads/system/uploads/atta chment_data/file/427124/webtag-tag-unit-m3-1-highway-assignmentmodelling.pdf.

Department for Transport. 2017. "TAG UNIT A1.3 User and Provider Impacts." Department for Transport, accessed 24 June 2018. https://www.gov.uk/government/uploads/system/uploads/attachment_data/file/6 03254/webtag-tag-unit-a1-3-user-and-provider-impacts-march-2017.pdf.

DMJM Harris. 2001. "Monorail Technology Assessment." DMJM Harris, accessed 14 July 2018. https://www.montgomerycountymd.gov/DOTTransit/Resources/Files/techreportfinalreport.pdf.

European Environment Agency. 2015. "Occupancy Rates of Passenger Vehicles." European Environment Agency, accessed 6 September 2017. https://www.eea.europa.eu/data-and-maps/indicators/occupancy-rates-ofpassenger-vehicles/occupancy-rates-of-passenger-vehicles-1.

Government of Vietnam. 2016. "Approval of Transportation Master Plan in Hanoi up to 2030 with a Vision Towards 2050." Government of Vietnam, accessed 28 April 2017.

http://vanban.chinhphu.vn/portal/page/portal/chinhphu/hethongvanban?class_id $=2 \&$ mode=detail\&document_id=184101.

Gwilliam, Ken, Masami Kojima, and Todd Johnson. 2004. "Reducing Air Pollution from Urban Transport." World Bank, accessed 30 June 2017. http://documents.worldbank.org/curated/en/989711468328204490/pdf/304250P APER0Reducing0air0pollution.pdf.

Hall, Jonathan V., and Alan B. Krueger. 2018. "An Analysis of the Labor Market for Uber's Driver-Partners in the United States." ILR Review 71 (3):705-732. doi: 10.1177/0019793917717222.

Hanna, Rema, Gabriel Kreindler, and Benjamin Olken. 2017. "Citywide Effects of High-occupancy Vehicle Restrictions: Evidence from “Three-in-one” in Jakarta." Science 357 (6346):89-93. 
Hanoi Transport Management and Operation Centre. 2011. Detailed Plan for the Bus Network System in Hanoi from 2010 to 2020. Hanoi: Hanoi Department of Transport.

Hensher, David, and Thomas Golob. 2008. "Bus Rapid Transit Systems: A Comparative Assessment." Transportation 35 (4):501-518.

Li, Xucheng. 2015. "A Comparative Assessment for Innovative Public Transport Technologies." PhD thesis, University of Southampton.

Li, Xucheng, and John Preston. 2015a. "Assessing the Financial and Social Costs of Public Transport in Differing Operating Environments and with Endogenous Demand." Transportation Planning and Technology 38 (1):28-43.

Li, Xucheng, and John Preston. 2015b. "Reassessing the Financial and Social Costs of Public Transport." Proceedings of the ICE-Transport 168 (4):356-369.

Maibach, Markus, Christoph Schreyer, Daniel Sutter, Huib Van Essen, Bart Boon, Richard Smokers, Arno Schroten, Doll Claus, Barbara Pawlowska, and Monika Bak. 2007. Handbook on Estimation of External Cost in the Transport Sector. Delft: CE Delft.

Malaysia Economic Planning Unit. 2010. "Tenth Malaysia Plan 2011 - 2015." Malaysia Economic Planning Unit, accessed 20 September 2018. https://www.pmo.gov.my/dokumenattached/RMK/RMK10_Eds.pdf.

Manoratna, Dinushi A., Keisuke Kawata, and Yuichiro Yoshida. 2017. "Environmental Impact and Travel Time Savings of a New Monorail System in Colombo’s Commuting Traffic." Transportation Research Part D: Transport and Environment 51:122-128. doi: 10.1016/j.trd.2016.12.003.

Meyer, John R., John F. Kain, and Martin Wohl. 1965. The Urban Transportation Problem. London: Oxford University Press.

Nellthorp, John, Abigail L. Bristow, and Brett Day. 2007. "Introducing Willingness-topay for Noise Changes into Transport Appraisal: An Application of Benefit Transfer." Transport Reviews 27 (3):327-353. doi: 10.1080/01441640601062621.

Nguyen, Cao Y., Kazushi Sano, and Cong M. Chu. 2007. "Dynamic Motorcycle Unit and Mean Stream Speed under Mixed Traffic Conditions on Urban Roads." Journal of the Eastern Asia Society for Transportation Studies 7:2439-2453.

Rogers, Martin, and Aidan Duffy. 2012. Engineering Project Appraisal. Chichester: John Wiley \& Sons. 
Sansom, Tom, Chris Nash, Peter Mackie, Jeremy Shires, and Paul Watkiss. 2001.

Surface Transport Costs and Charges: Great Britain 1998. Report

commissioned by the Department of Environment, Transport and the Regions.

Leeds: Institute for Transport Studies, University of Leeds and AEA Technology

Environment.

Schneider, Henrique. 2017. Uber: Innovation in Society. Switzerland: Springer.

Small, Kenneth A. 1983. "Bus Priority and Congestion Pricing on Urban Expressways." Research in Transportation Economics 1:27-74.

Small, Kenneth A., and Erik T. Verhoef. 2007. The Economics of Urban Transportation. New York: Routledge.

Sugiyanto, Gito, Siti Malkhamah, Ahmad Munawar, and Heru Sutomo. 2011.

"Estimation of Congestion Cost of Motorcycles Users in Malioboro,

Yogyakarta, Indonesia." International Journal of Civil \& Environmental

Engineering (IJCEE-IJENS) 11 (01):56-63.

Taxi Group. 2018. "Taxi group ban xe taxi thuong quyen san bay noi bai." Taxi Group, accessed 25 July 2018. https://taxigroup.net/taxi-group-ban-xe-taxi-thuongquyen-san-bay-noi-bai/.

Transport Engineering Design Incorporated. 2013. Transportation Master Plan in Hanoi up to 2030 with a Vision Towards 2050. Hanoi: Department of Transport. Transport Research Partners. 2016. Glasgow Taxi Cost Model 2016 - Review of Taxi Tariffs in the City of Glasgow for the period February 2015 - February 2016. Glasgow: Glasgow City Council.

Tsai, Jiun-Horng, Hung-Lung Chiang, Yi-Chun Hsu, Bo-Jun Peng, and Rong-Fang Hung. 2005. "Development of a Local Real World Driving Cycle for Motorcycles for Emission Factor Measurements." Atmospheric Environment 39 (35):6631-6641. doi: 10.1016/j.atmosenv.2005.07.040.

Uber. 2018. "What Is the Uber Fee?". Uber, accessed 06 August 2018. https://help.uber.com/h/5704e643-6df8-47ce-bcb2-a3968a445bcc.

Vu, Van H., Xuan Q. Le, Ngoc H. Pham, and Luc Hens. 2013. "Health Risk Assessment of Mobility-Related Air Pollution in Ha Noi, Vietnam." Journal of Environmental Protection 04 (10):1165-1172. doi: 10.4236/jep.2013.410133.

Wang, Rui. 2011. "Autos, Transit and Bicycles: Comparing the Costs in Large Chinese Cities." Transport Policy 18 (1):139-146. 
Wardman, Mark, Phani K. Chintakayala, and Gerard de Jong. 2016. "Values of Travel Time in Europe: Review and Meta-Analysis." Transportation Research Part A: Policy and Practice 94:93-111. doi: 10.1016/j.tra.2016.08.019.

World Bank. 2015a. "International Development Association Project Appraisal Document on a Proposed Credit in the Amount of SDR 88.2 million (US\$124.0 million) to the Socialist Repuplic of Vietnam for the Ho Chi Minh City Green Transport Development Project." World Bank, accessed 30 May 2017. http://documents.worldbank.org/curated/en/558961468179946764/pdf/PAD130 5-PAD-P126507-IDA-R2015-0120-1-Box391444B-OUO-9.pdf.

World Bank. 2015b. "PPP Conversion Factor, GDP ". World Bank, accessed 22 May 2017. http://data.worldbank.org/indicator/PA.NUS.PPP?end=2015\&start=2011. World Bank. 2017. "Fundamentals of Purchasing Power Parities." World Bank, accessed 28 May 2018. http://pubdocs.worldbank.org/en/332341517441011666/PPP-brochure-2017webformat-rev.pdf.

World Bank. 2019. "Classifying Countries by Income." World Bank, accessed 30 September 2019. https://datatopics.worldbank.org/world-developmentindicators/stories/the-classification-of-countries-by-income.html. 


\section{Appendices}

Table 5 An example for calculating ASC of one exclusive motorcycle (MC) lane per direction corridor with a demand of 10,000 pax/direction/day

\begin{tabular}{|c|c|c|c|}
\hline $\begin{array}{c}\text { Cost } \\
\text { elements }\end{array}$ & $\begin{array}{l}\text { Key parameters / short } \\
\text { description }\end{array}$ & $\begin{array}{l}\text { Values } \\
\text { (round } \\
\text { numbers up) }\end{array}$ & Notes \\
\hline & Total demand, $D$ & 10,000 & Unit is pax/direction/day. \\
\hline & Journey length, $J L(\mathrm{~km})$ & 4 & \\
\hline & Annualisation factor, $a$ (day) & 261 & \\
\hline & $\begin{array}{l}\text { Annual Passenger-km for both } \\
\text { directions, } P K M\end{array}$ & $20,880,000$ & $P K M=2 * D * J L * a$ \\
\hline & $\begin{array}{l}\text { Demand for Morning/Afternoon } \\
\text { peak hour (Period 1), D1 }\end{array}$ & 1,000 & $\begin{array}{l}D 1=10 \% * D \text { (see Table } 4) \text {. Unit is } \\
\text { pax/direction/hour. }\end{array}$ \\
\hline & Corridor length, $L(\mathrm{~km})$ & 7 & \\
\hline & MC occupancy, $M C \_O$ & 1.22 & \\
\hline & Annual MC-km & $17,114,754$ & Annual MC.km $=P K M / M C \_O$ \\
\hline & MC flow in Period 1, Q1 (MC/h) & 820 & $Q 1=D 1 / M C \_O$ \\
\hline & $\begin{array}{l}\text { MC speed on links in Period 1, V1 } \\
(\mathrm{km} / \mathrm{h})\end{array}$ & 38.92 & $\begin{array}{l}\text { As } Q 1<C, V 1 \text { is calculated as } V_{\text {Nocap }} \text {, which } \\
\text { is shown in Equation } 4 .\end{array}$ \\
\hline & $\begin{array}{l}\text { Travel time per one trip in Period } \\
1, T T 1 \text { (hour) }\end{array}$ & 0.136 & $\begin{array}{l}T T 1=J L / V 1+0.033 \text {. Assume that travel } \\
\text { time at intersections is } 0.033 \text { hours. }\end{array}$ \\
\hline & $\begin{array}{l}\text { Total travel times per direction per } \\
\text { day, TTPD (hour) }\end{array}$ & 1,110 & $\begin{array}{l}\text { Travel time per trip is calculated in different } \\
\text { periods showing in Table } 4 \text {. Then, TTPD is } \\
\text { sum of travel times of all periods of day. }\end{array}$ \\
\hline & $\begin{array}{l}\text { Value of time for MC in Hanoi, } \\
M C \_V O T \text { ( } £ / \text { hour in } 2015 \text { prices) }\end{array}$ & 1.54 & \\
\hline $\begin{array}{l}\text { 1. Annual } \\
\text { travel time } \\
\text { costs }\end{array}$ & These are variable costs. & $\begin{array}{l}890,184 \\
\text { (£/year) }\end{array}$ & $\begin{array}{l}\text { Annual travel time costs for both directions } \\
\text { are equal to } 2^{*} a^{*} M C_{-} V O T^{*} T T P D \text {. These } \\
\text { costs are related to speed. }\end{array}$ \\
\hline $\begin{array}{l}\text { 2. Annual } \\
\text { delay costs }\end{array}$ & $\begin{array}{l}\text { The congested-related delay costs } \\
\text { are variable costs. }\end{array}$ & $\begin{array}{l}88,386 \\
\text { (£/year) }\end{array}$ & $\begin{array}{l}\text { Based on methods to estimate reliability } \\
\text { from Department for Transport (2017). These } \\
\text { costs are related to speed. }\end{array}$ \\
\hline $\begin{array}{l}\text { 3. Annual } \\
\text { vehicle } \\
\text { capital costs }\end{array}$ & $\begin{array}{l}\text { These are variable costs, which are } \\
\text { products of MC capital cost per } \\
\text { MC-km and Annual MC-km. }\end{array}$ & $\begin{array}{l}658,978 \\
\text { (£/year) }\end{array}$ & $\begin{array}{l}\text { Average annual distance one motorcyclist } \\
\text { travels is adapted from the study of Transport } \\
\text { Engineering Design Incorporated (2013). } \\
\text { Then MC capital cost is estimated as } 0.0385 \\
(£ / M C-k m) \text {. }\end{array}$ \\
\hline $\begin{array}{l}\text { 4. Annual } \\
\text { operating } \\
\text { costs }\end{array}$ & $\begin{array}{l}\text { These are semi variable costs. } \\
\text { Operating cost for } 1 \text { motorcycle in } \\
\text { Period } 1 \text { is calculated as } 0.059 \\
\text { (PPP } £ / \mathrm{km} \text { ). }\end{array}$ & $\begin{array}{l}254,927 \\
\text { (£/year) }\end{array}$ & $\begin{array}{l}\text { Based on the relationship between MC } \\
\text { operating costs and speed from the study of } \\
\text { Sugiyanto et al. (2011). These costs, which } \\
\text { are related to speed, are estimated for all } \\
\text { periods of day, then for whole day. }\end{array}$ \\
\hline $\begin{array}{l}\text { 5. Annual } \\
\text { maintenance } \\
\text { costs }\end{array}$ & $\begin{array}{l}\text { These are variable costs, which are } \\
\text { products of maintenance cost per } \\
\text { MC-km and Annual MC-km. }\end{array}$ & $\begin{array}{l}36,515 \\
\text { (£/year) }\end{array}$ & $\begin{array}{l}\text { The total maintenance costs for Hanoi entire } \\
\text { road networks are allocated into motorcycle, } \\
\text { car and bus based on total kilometre travelled } \\
\text { by modes. Then the MC maintenance cost is } \\
\text { estimated as } 0.213 \text { (p/MC-km). }\end{array}$ \\
\hline $\begin{array}{l}\text { 6. Annual } \\
\text { parking costs }\end{array}$ & $\begin{array}{l}\text { These are fixed costs, which are } \\
\text { products of average parking cost } \\
\text { per MC-km and Annual MC-km. }\end{array}$ & $\begin{array}{l}179,705 \\
\text { (£/year) }\end{array}$ & $\begin{array}{l}\text { The average parking cost is estimated as } 1.05 \\
(\mathrm{p} / \mathrm{MC}-\mathrm{km}) \text {. }\end{array}$ \\
\hline $\begin{array}{l}\text { 7. Annual } \\
\text { infrastructure } \\
\text { costs }\end{array}$ & $\begin{array}{l}\text { These are fixed costs, which are } \\
\text { the product of annual infrastructure } \\
\text { cost per km and } L \text {. }\end{array}$ & $\begin{array}{l}8,434,363 \\
\text { (£/year) }\end{array}$ & $\begin{array}{l}C R F=r *(1+r)^{m} /\left((1+r)^{m}-1\right) . r \text { is DR, } 12 \% . m \\
\text { is life expectancy of infrastructure, } 20 \text { years. } \\
\text { Annual infrastructure cost per km is the } \\
\text { product of infrastructure cost per km and } \\
\text { CRF. }\end{array}$ \\
\hline TUC & $T U C=(1)+(2)+(3)$ & $1,637,548$ & Unit cost is $£ /$ year. \\
\hline TOC & $T O C=(4)+(5)+(6)+(7)$ & $8,905,510$ & Unit cost is $£$ /year. \\
\hline TEC & $\begin{array}{l}\text { These are variable costs, which are } \\
\text { products of external unit costs and } \\
\text { annual Passenger-km. }\end{array}$ & 465,207 & $\begin{array}{l}\text { Unit cost is } £ \text { year. These costs include air } \\
\text { pollution, noise pollution, climate change } \\
\text { and accidents costs. }\end{array}$ \\
\hline TSC & $T S C=T U C+T O C+T E C$ & $11,008,265$ & Unit cost is $£ /$ year, in 2015 prices. \\
\hline ASC & $A S C=T S C * 100 / P K M$ & 52.72 & Unit cost is p/pax-km, in 2015 prices. \\
\hline
\end{tabular}


Table 6 An example for calculating ASC of the elevated Metro option with a demand of 100,000 pax/direction/day

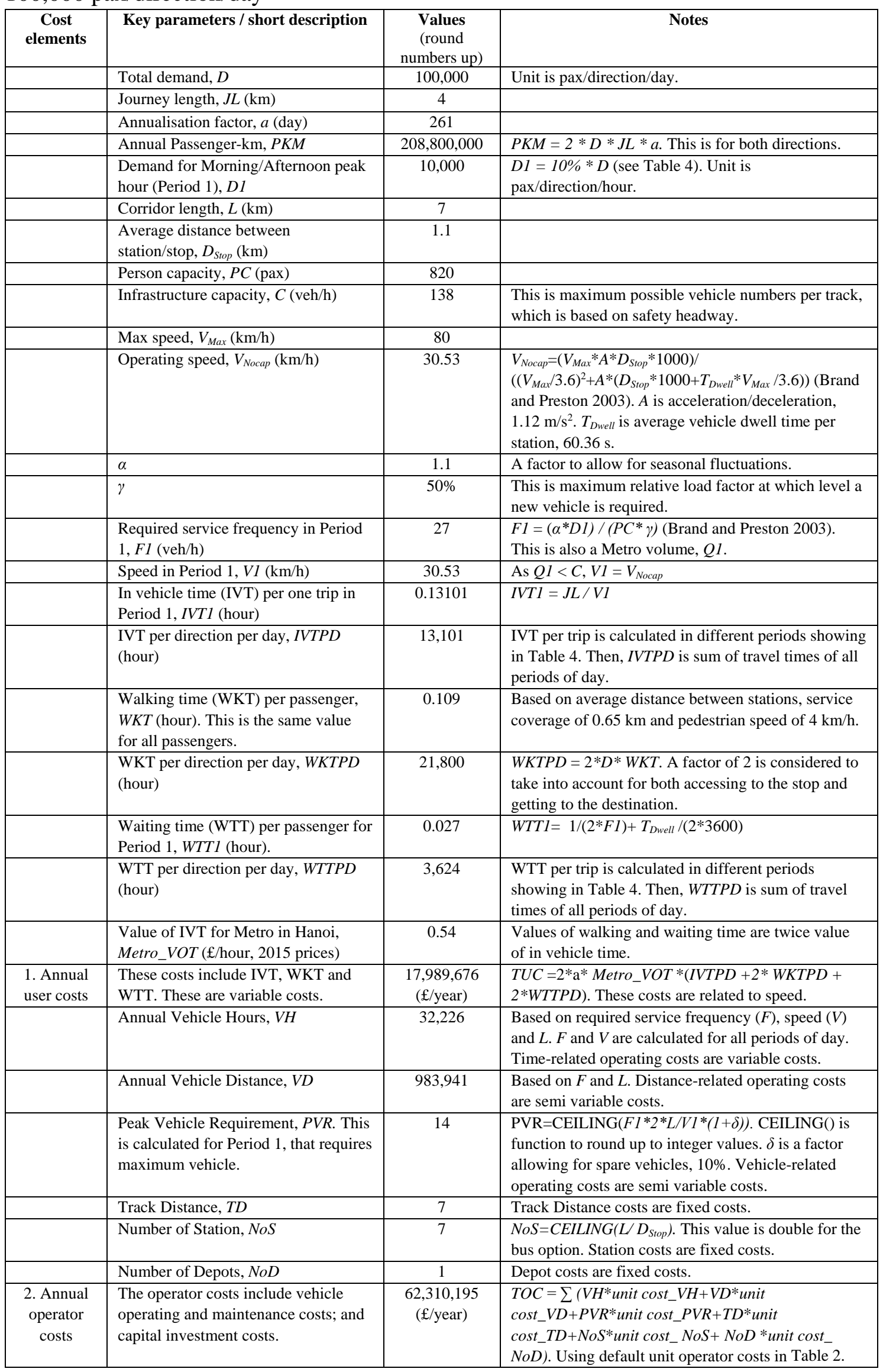




\begin{tabular}{|c|l|c|l|}
\hline $\begin{array}{c}\text { Cost } \\
\text { elements }\end{array}$ & Key parameters / short description & $\begin{array}{c}\text { Values } \\
\text { (round } \\
\text { numbers up) }\end{array}$ & Notes \\
\hline $\begin{array}{c}\text { 3. Annual } \\
\text { external } \\
\text { costs }\end{array}$ & $\begin{array}{l}\text { These are variable costs, which are } \\
\text { products of external unit costs and } \\
\text { annual Passenger-km. }\end{array}$ & $\begin{array}{c}6,245 \\
(£ / \text { year) }\end{array}$ & $\begin{array}{l}\text { These costs include air pollution, noise pollution, } \\
\text { climate change and accidents costs. Using default } \\
\text { unit external costs in Table 3. }\end{array}$ \\
\hline TSC & $T S C=T U C+T O C+T E C$ & $80,306,116$ & Unit cost is $£ /$ year, in 2015 prices \\
\hline ASC & $A S C=T S C^{*} 100 / P K M$ & 38.46 & Unit cost is p/pax-km, in 2015 prices. \\
\hline
\end{tabular}

